\title{
PLACING CHINA IN THE WORLD HISTORY OF DISCOVERY, PRODUCTION, AND USE
}

The Bayan Obo mine in Inner Mongolia, China, was once a sacred Mongolian site and an area in which competing empires fought for control. How did this place become the single greatest source of rare earth elements in the world?

Even after several years of diversification in the global supply chain, the Bayan Obo mine remains the single greatest source of rare earth elements in the world, producing approximately 50 percent of the global supply. As recently as 2013, it was thought to be the largest rare earth deposit on Earth (Ling et al. 2013). As this chapter shows, the discovery of Bayan Obo's mineral wealth was an outcome of competing territorial, industrial, and cultural campaigns to transform the frontier into a larger resource hinterland for China, the former USSR, and other imperial powers. These campaigns laid the foundation for the Bayan Obo mine in Baotou, Inner Mongolia Autonomous Region (IMAR), shown in figures 6 and 7, to later become the "Rare Earth Capital of the World," as it is called in contemporary literature and domestic parlance in China.

China's de facto monopoly is mythologized in contemporary rare earth discourse: "China as the world's richest rare earth nation" or "the only nation possessing all seventeen types of rare earth elements" (Wang 2010,15) was a common trope in popular commentary in China and across the globe in the years immediately following the 2010 crisis. This trope revived the theories of Malthus (1798) and Hotelling (1931), which stated that as population grows and demand 


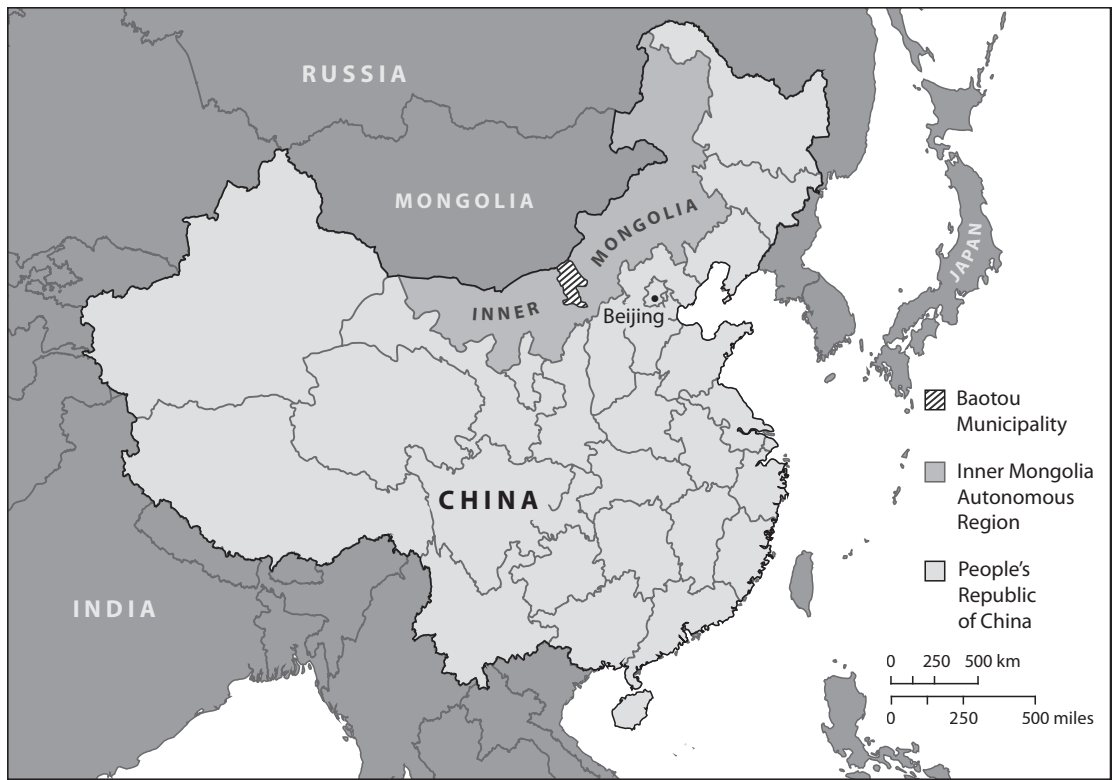

FIGURE 6. Baotou municipality is located in Inner Mongolia Autonomous Region, People's Republic of China. It borders Mongolia to the north and the Yellow River to the south.

Source: Image by Molly Roy.

increases, nonrenewable resources will be depleted, leading to higher prices, conflict, and suffering.

These myths of China's legendary rare earth endowment, buttressed with neoMalthusian logic, have generated three contradictory outcomes. First, the myth of China as the world's richest rare earth nation has been deployed in domestic discourse to justify recentralization and greater state control over production (Cheng and Che 2010). This has had both positive and negative consequences. On the one hand, the state has placed greater importance on environmental conservation and regulation. On the other hand, state-run media has used the rare earth scarcity myth to reframe legitimate concerns over production practices into a nationalist paranoia about how the rest of the world is conspiring to pillage China's strategic mineral wealth (Wang 2010). Second, outside of China, the myth of rare earth scarcity justified prospecting in places previously considered off-limits, such as the Brazilian Amazon, Greenland, and the Moon. Third, China's purported geological privilege has been useful internationally to justify the World Trade Organization (WTO) suits brought by the United States, Japan, and the European Union against China's production and export quotas, based on the 


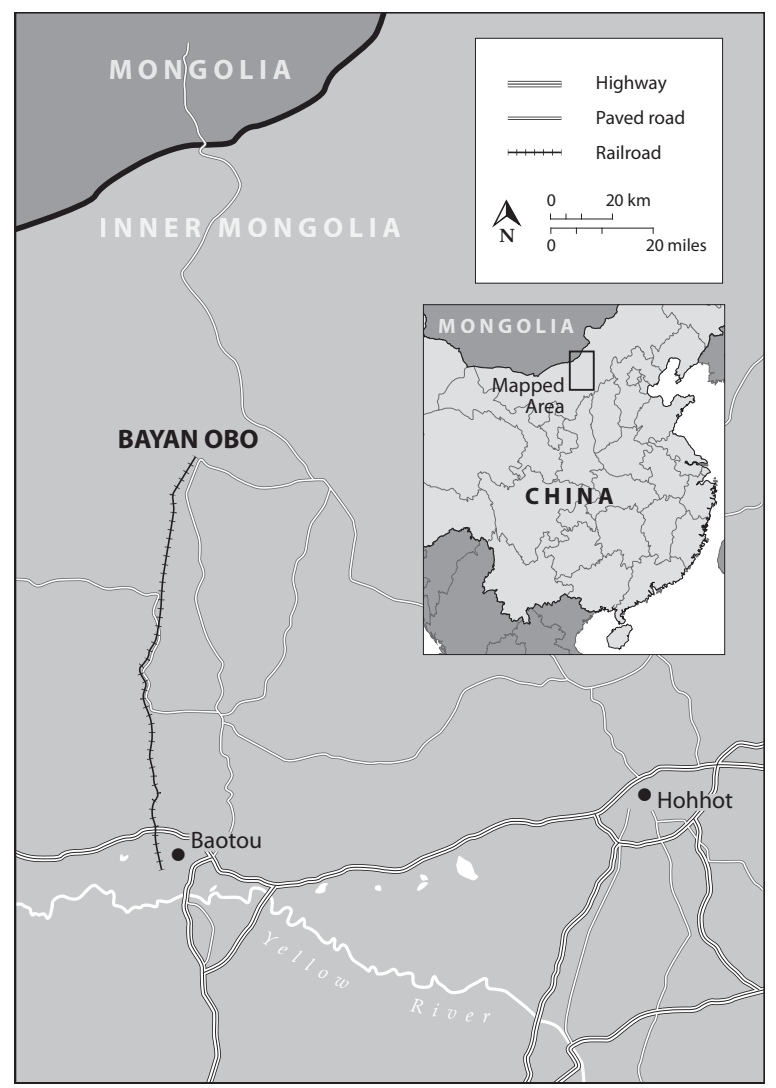

FIGURE 7. The Bayan Obo mine is located in the northernmost portion of Baotou Municipality. One rail and one road connect it with Baotou City, located in southern Baotou Municipality along the Yellow River. Due to the scarcity of water in the north, the heavy industry, urban, military, and supporting agricultural bases are located in Baotou City, in the south. Major highway and rail lines connect Baotou City to the south, east, and west.

Source: Image by Molly Roy.

argument that because the rest of the world depended on China's reserves, the quotas gave China an unfair advantage. Paradoxically, the successful suit against China to remove its production and export quotas in 2014 had the effect of bringing prices of some elements closer to precrisis levels, thereby eliminating the incentive for others outside of China to invest in the technological development necessary to mine rare earths in a more sustainable manner.

Although the Malthus and Hotelling theories possess a compelling logic, logic is not the same as truth. As with most nonrenewable resources, the global rare 
earth supply is not fixed. It is true that at any given period there is only a certain quantity of known reserves; however, the historical tendency shows that as resources are depleted, new deposits are found. Peak resource paranoia aside, we are so far from exhausting global rare earth reserves that the possibility does not merit serious consideration. Indeed, since the 2010 crisis, estimates of China's reserves as a percentage of the global total have been decreasing annually, from 50 percent in 2009 to 23 percent in 2012 (Chen 2011; United States Geological Survey 2014; Zhao quoted in Hilsum 2009; see also Information Office of the State Council 2012).

This percentage does not account for the discovery of the largest known global deposit at the bottom of the South Pacific or the undetermined but reportedly immense finds in North Korea (Bruce 2012; Evans-Pritchard 2013; Kato et al. 2011; Schearf 2014). As the post-2010 wave in global prospecting and research illustrated, scarcity-induced price increases incentivized exploration ever further afield, as well as investment in the technologies required to exploit resources in remote places. Indeed, China's Bayan Obo deposits were discovered under precisely these conditions several decades ago when competing imperial powers were seeking iron to build military-industrial complexes and uranium for their nuclear efforts. Therefore, China's contemporary rare earth dominance is only marginally explained by geological circumstance. Most countries have enough reserves to be self-sufficient (Baltz 2013). ${ }^{1}$

Chapter 1 detailed the pre- and postwar production history of rare earth elements-a history that spanned the globe. This chapter centers that global history within China, whose mineral resources, struggles over their definitions, and their role in state building played a critical role in the global politics of the early twentieth century. In the mid-twentieth century, Mao Zedong and Joseph Stalin's agenda to convert the windswept steppes of Inner Mongolia into a militaryindustrial heartland that could provision both Republics in the struggle against western capitalism and Japanese imperialism laid the foundation for China's longterm rare earth development.

This history underscores the point that China's rare earth monopoly arose from particular political and economic circumstances-some only marginally related to rare earth elements-rather than fabled resource abundance. The concentration of global production in China followed a contingent and uneven process over the course of several decades of cultural, political, and economic transformations across the globe. These transformations included post-World War II decolonization, Cold War politics, the global liberalization of capital, and the emergence of a shifting global division of toxic labor. This chapter and the following one seek to overcome the tendency in Sinophone, Anglophone, and Lusophone literature to attribute China's rare earth monopoly to geological deter- 
minism and the foresight of the Chinese state, on the one hand, or the vagaries of global (Western) capitalism, on the other. Rather, these chapters tell a very different story, presented in two parts: chapter 2 considers the territorial contests that were instrumental to carving IMAR, Baotou, and Bayan Obo out of the expanse of the Mongolian Steppe, whereas chapter 3 examines subsequent global shifts in political economy characterized by Deng Xiaoping's reforms and the Reagan/Thatcher counterrevolution.

Too often, the rise of Bayan Obo is explained in terms of Western industry migrating to China. Such analyses follow closely on the "impact model of globalization" (Hart 2002), wherein change unilaterally emanates from "the West" to remake "the Rest" in its own image (Hall 1992). There is some truth to such models, but also a great deal of historical illiteracy. To understand how and why Bayan Obo emerged as the rare earth capital of the world requires an in-depth examination of the world-historical processes from which our contemporary situation emerged. Without the foundations laid by decades of prospecting, frontier taming, and hinterland development activities, Baotou and Bayan Obo would not have been in the position to assume primacy in rare earth mining and processing when the industry left the west a few decades ago.

Most contemporary stories of China begin in 1949 and position the central government as the primary driver of history. However significant state planning is to contemporary industrial development, it is important to remember that China's de facto monopoly was not predestined. For the first half of the twentieth century, Bayan Obo, and indeed much of what is today IMAR was claimed by several competing powers: Japan, Chinese Nationalists, Communists, Mongolians, and Soviets, while more remote powers in the Euro-American world coveted IMAR's undiscovered mineral wealth.

To illustrate the uncertainty of China's consolidation of power over Bayan Obo, and to show the monumental scale of the task of industrializing Bayan Obo and Baotou, this chapter examines how multiple territorial ambitions-even those which were ultimately unfulfilled-were crucial to laying the foundation for Bayan Obo to emerge as the hometown of rare earths. Exploring this history provides two key insights. First, the establishment of Bayan Obo as the primary source of rare earths consumed worldwide was far from inevitable. The second insight, which holds important lessons for the future, is that the world's only long-running, diversified, and vertically integrated rare earth production site to date was built through deliberate, sustained, and internationally collaborative efforts.

There are several important lessons to be drawn from the historical record as we consider our possible pathways forward. The complexity of the history presented here shows that the development and management of rare earth resources 
has always been a complex and uncertain endeavor. Our current state of affairs was built on a combination of myths, violently exercised territorial ambitions, and breathtaking scientific and technological change. Terrible and wonderful things both emerged from these historical processes. We choose which we carry forward. To make an informed decision, we must look squarely at the past.

The foundation for China's rare earth monopoly was laid through three key processes, each discussed in turn. I first discuss how Baotou was the object of the territorial ambitions of several powers in the first half of the twentieth century. Geological knowledge production served as a tool of competing empires, and later, after the founding of the People's Republic of China (PRC) in 1949, as a basis for nation building and internal colonization. Next, I demonstrate that, contrary to possessing a grand strategy to use its rare earth monopoly to hold the world hostage (as many Anglophone and Lusophone commentators have alleged), the development of China's rare earth capital emerged from a broader policy to tame a border and create a red hinterland out of a historically stateless steppe using violence, military-industrial development, and cultural campaigns targeted toward different ethnic and gender groups. "Red hinterland" is a term that captures the production of inland resource bases as part of the socialist industrialization project between China and the USSR in the 1950s, as both powers sought to gain control over the historically dynamic territorial politics in what is today contemporary IMAR. I then examine the significance of atomic aspirations to consolidating the transformation of the inland frontier into a military-industrial hinterland, even amid national and international turmoil. These atomic aspirations and attendant visions of a socialist nation leading the global revolution laid the foundation for China's contemporary rare earth dominance. Over time, a changing cast of actors ascribed different meanings to rare earths as knowledge and politics changed. Each played a critical role in China's emergence as the rare earth capital of the world in ways that could hardly be foreseen.

\section{Inland Frontier: Geology, Imperialism, and Nationalism}

And China began its survey in the early years of the twentieth century as it endeavoured to build up military and economic strength to combat Western and Japanese imperialist threats. It was the powerful countries that interested themselves in matters geological; and so it has continued to the present day (with power now projected under the oceans and toward other regions of the solar system). 
Global rare earth extraction in the first half of the twentieth century was defined by colonial power, driven by the resource demands of war and industrial modernization, and accelerated by the fervor of the atomic age. In this time of shifting empires, revolutions, and world wars, the sacrifice of certain peoples and places was taken for granted in the service of grand ambitions. The complexity of this situation in China deserves special treatment, as competing imperialist and nationalist interests surveyed China's terrain with the intention of rationalizing a mysterious empire. Fundamental to this was the expanding scope of global geological prospecting alongside the reconfiguration of geological knowledge as a tool of state power in the global struggle between communism and capitalism (Underwood and Guth 1998; United States Department of the Army 1952). The deposits at Bayan Obo were discovered in this context.

Geology evolved as a science of territoriality (Braun 2000; Winchester 2009). It is a way to rationalize terra incognita in the service of state, empire, and nation building. The evolution of geological science in China is inseparable from imperial designs on China's territory and resources, beginning in the late Qing dynasty during the latter decades of the nineteenth century (Shen 2014; Wu 2010). In the 1880s, colonial actors in the German Foreign Ministry looked to China to expand their reach with the objective of eclipsing the more extensive British and French empires. The strategy for achieving this was overwhelmingly material: diplomatic transmissions from both the Chinese and the German sides were dominated with concerns over mining technology transfer, land use, and mining rights (Wu 2010). During this period, Western missionaries sought to capitalize on Chinese interest in the industrialization of the Euro-American world. Their strategy was to educate their target populations in science and technology in order to legitimate ongoing efforts at religious conversion. Hence the quest for souls on the southern Mongolian steppe directed competing imperial interests through the late nineteenth and early twentieth century, which geological interests followed. ${ }^{2}$

Geological survey teams from Germany, Japan, the Soviet Union, and China prospected in the steppe and desert of what was to become, in 1947, the Inner Mongolia Autonomous Region. Each team came to survey the region with the intention of bounding its geological wealth into a larger resource hinterland, whether for imperial Europe, Nazi Germany, imperial Japan, or the USSR. It is worth noting that the industrial orientation of geological survey activities, the cartographic portrayal of mineral wealth, and the construction of the infrastructure required to extract it were viewed as symbols of progress and modernity for imperialist, nationalist, capitalist, and communist interests alike (Davis 1926). Struggles around these developments were not necessarily struggles against industrialization or mining per se, but rather struggles over their meaning and purpose. Where imperial powers saw the extension of their surveyors and technologies to China as 
tangible evidence of the reach of their empires, Chinese nationalists viewed foreign-constructed mines, railways, roads, and ports as symbols of imperialist humiliation, which had to be reclaimed and improved for the development of the Chinese nation (Chen and Yao 1954).

China's Geological Society was the first scientific institution established in modern China in 1922 under the Republican government, with the express purpose of understanding the nation. As Shen $(2014,13)$ observes: "any viable understanding of the nation had to suit the twin criteria of protecting Chinese existence and promoting geological activity, and often the boundaries of one effort would shift to accommodate the other." Early geological research activity in China was characterized by international collaboration and open exchange of information. ${ }^{3}$ The first meetings of the geological society featured international speakers, which cultivated Beijing's reputation as "the center of scientific life in Asia" (Shen $2014,102)$. There was considerable inequality between Chinese and foreign researchers, however. The former were cash-strapped and relied on state directives and commissions from mining companies to keep China's Geological Society afloat. The latter were convinced that only an established colonial power could tackle the vast unknown of China's geology. To these observers, Japan appeared to be particularly well positioned, with control over key infrastructure extending inland from northeastern and southeastern China (Margerie in Wu 2014, 5n).

This infrastructure was built to consolidate imperial Japanese control over northern China, where Japan organized local puppet governments, engaged in prospecting activities, and took over heavy industry and munitions factories. In the 1930s, Japan occupied almost one-third of China, primarily the coastal and northern regions where the majority of China's government, research, and industry were located. The joint Communist-Guomindang $(\mathrm{KMT})^{4}$ forces organized a mass retreat to the interior while the militaries attempted to block the Japanese army's westward advance. Chinese geologists and other technically trained personnel focused on opening up new resource bases in central and western China to provide the raw materials needed in the war of resistance against Japan $\mathrm{Wu}$ 2010). The force of China's resistance surprised imperial Japan and Western observers; instead of conquering the whole of China in three months' time as predicted (Utley 1937), China's defensive compelled Japan to pour ever more resources into their conquest of the mainland until their surrender in 1945.

A key part of China's resistance involved building an international presence. From the late 1920s through the 1930s, the KMT sought to reunify China, integrate its economy with the world economy, and engage as equals in international relations. During this time, Germany exerted arguably the greatest influence among the KMT’s governing elite. Chiang Kai-shek viewed Prussian fascism as a 
model of rapid national development to emulate in order to mobilize and discipline the populace into breathing "New Life"5 into the nation (Kirby 1984). To revive the German economy struggling in the aftermath of World War I and the global slowdown of the Great Depression, the Nazi leadership looked to China as both a resource hinterland and an immense potential market for German industry. The two countries brokered a set of barter agreements in which China would exchange raw materials for German military equipment, ${ }^{6}$ railroad materials, and industrial equipment. The German government also sponsored Chinese students to receive training in Germany-when they returned to China, many staffed agencies overseeing the country's industrial and military modernization (Kirby 1984).

China exported tungsten, antimony, tin, and copper, which were crucial for Germany's post-World War I rearmament. Tungsten is an important element of war because it is extremely hard, so it is used to make projectiles. It also has the lowest coefficient of thermal expansion of any pure metal, making it an important predecessor to rare earth superalloys in the construction of airplane engines, tanks, rockets, and other steel alloys (Li 1955). Antimony was used to build ignition switches, produce flame retardants, and harden the lead used in bullets (Butterman 2004). Both preceded rare earth elements in the development of modern industry and warfare. ${ }^{7}$ However, they were heavy and cracked unpredictably, so scientists sought replacements. It is important to note that while the 2010 crisis stimulated the search for rare earth replacements, rare earths themselves were once replacements for other materials.

Germany provided the majority of Nationalist China's foreign credit, so the KMT worked to increase China's mineral output as much as possible in order to generate foreign exchange (Kirby 1984). This meant consolidating KMT control over a fragmented territory and acquiring the geological knowledge necessary to exploit it. Geological prospecting is one means to settle territory, but building sovereignty through geological survey is a risky affair when multiple powers are involved. The KMT enlisted German, Swiss, and Danish experts to explore and map the subsoils of Inner Mongolia and Xinjiang. The international teams of geologists, archeologists (including John Gunnar Andersson), and geographers (including prominent Swiss geographer Sven Hedin) formed the Northwestern Scientific Expedition Team (xibei kexue kaocha tuan), which identified mineral, fossil, and archeological treasures in this inland frontier (Deng 2007; Hedin et al. 1944).

In April 1927, this team of forty left Beijing by train and traveled to Baotouthen a border outpost before the "uninhabited" steppe and desert—where they provisioned themselves for the long prospecting journey by mule and camel from Baotou to Alashan tribe in Ejina Banner (Xing and Lin 1992). In July of that year, when visiting a sacred mountain in southern Mongolia, geologist Ding Daoheng 
discovered the resources at Bayan Obo (Ding 1933). Although he is upheld as a national hero for identifying what was, for a long time, thought to be the world's largest rare earth deposit, he was part of a group within the expedition that was entirely focused on identifying iron sources to provision the German, Soviet, and nascent KMT industries. The presence of rare earths at Bayan Obo was not demonstrated until ten years later by the chemist He Zuolin ${ }^{8}$ (Zhang 1995). Ding Daoheng's legacy as the discoverer of Bayan Obo's rare earth elements was established only at the end of the twentieth century.

Since Ding Daoheng remained active in the expedition for the entirety of its five-year duration-discovering dinosaur fossils and leading a KMT political expedition through Xinjiang — he did not publish his results until 1933 (Luo 2007). The following year he went to Berlin to complete his $\mathrm{PhD}$, a fact that is often excised from popular retellings of his illustrious career, which also tend to omit international collaboration or the fact that the purpose of the prospecting was to identify mineral resources for multiple states. He returned in 1937 and took up a teaching post in Wuhan during the Western retreat (Luo 2007). After the founding of the PRC in 1949, he served on various high-level committees in central and western China, but never returned to Bayan Obo. The narratives emerging in the early twenty-first century lionize him as a local hero. The Annals of the District of Bayan Obo reports that he wished deeply to return to the northern borderland so loaded with significance in his life and for the nation. When he received the "joyous news" of the government-planned "geological assault" on Bayan Obo in 1950, he reportedly looked northward, wept tears of excitement, and fervently uttered his best wishes for the exploitation of Bayan Obo to begin as quickly as possible (Zhao 2010, 386).

Technically, these resources were not China's to sell until after the founding of the PRC, and even then, jurisdiction over IMAR remained ambiguous. Despite retrospective accounts in China and elsewhere that treat the consolidation of Chinese control over Bayan Obo as inevitable, any number of territorial power arrangements were possible. At the time of the Northwest Scientific Expedition, Inner Mongolia was officially under the control of the Nationalist government of Chiang Kai-shek, headquartered in Nanjing over one thousand kilometers away. The native Mongolians organized themselves into unions ( $m e n g$ ), which were further divided into banners ( $q$ i), the latter of which collectively owned the soils and subsoils of Inner Mongolia. Although they maintained a certain degree of autonomy under the KMT despite the best efforts of the latter, there was a growing Pan-Mongolian independence movement. This was further provoked by the Chinese policy, initiated in the Qing and continued under the KMT, of encouraging Han migration to the region (Foreign Affairs Bureau 1916; Guomindang 1941). For centuries the sandy soils of Inner Mongolia had mostly discouraged large-scale 
migration by the agrarian Han Chinese. The soils can support fodder for nomadic pastoralists, but generally not for settled agriculture. Despite this, the Qing dynasty (1644-1911) began a resettlement campaign for Chinese peasants who had lost their land to war or natural disasters elsewhere in China. Although the Qing dynasty collapsed in 1911, before agrarian colonization extended into Mongolia, the Nationalist government adapted this strategy. It was renamed the "land reclamation program" (fangken) and was intended to alleviate land crises elsewhere while also taming the northern frontier by peopling it with Han Chinese. Over the first half of the twentieth century, this and related policies stimulated the migration of an estimated 4.5 million people, primarily Han Chinese, to the region that is now IMAR (Cai, Hai, and Sudehualige 2007).

Although Mongolia was officially under control of the KMT, southern Mongolian leadership strove for autonomy. Locals feared that their lands would be overwhelmed by the growing Han Chinese population and wanted independence from China. Mongolian Prince Demchegdongrov ${ }^{9}$ held a conference on Southern Mongolian self-rule in 1933, the year after the completion of the Northwest Scientific Expedition. The Imperial Japanese Army exploited this desire for independence by establishing a puppet government and organizing armies under Mongolian princes to fight on their side against China. Prince Demchegdongrov announced his break with the Chinese Nationalists in February 1936 and gathered his military at Bailingmiao located within present-day Baotou municipality, forty kilometers southeast of the Bayan Obo mining district. At the time, Bailingmiao and Bayan Obo were in two neighboring provinces, Chahar and Suiyuan, that have since been subsumed into Baotou municipality under Inner Mongolia's contemporary administrative units (Tighe 2005). On November 14, 1936, the Japanese-backed Mongolian army invaded Suiyuan in order to set up a puppet government and exploit the region's mineral wealth.

The Japanese-backed Mongolian Army was devastated by the ferocity of the KMT resistance led by General Fu Zuoyi. ${ }^{10}$ These battles over the future rare earth capital of the world marked the first time that the international press reported that Chinese forces successfully fought off Japanese-led forces, though Anglophone media was quick to attribute the success to military aid from Siberia, Czechoslovakia, and Indo-China (Jowett 2005; Syndicated Press 1937). Determined to capture Suiyuan and its mineral wealth under the guise of incorporating the territory into an independent Mongolian state ${ }^{11}$ (Associated Press 1937b), the Japanese and Mongolian forces led small-scale skirmishes over the next eight months (Jowett 2005). Bayan Obo remained under KMT control, ${ }^{12}$ but the historical coincidence of Ding Daoheng's discoveries and the threat of Japanese occupation are frequently cited in local histories in order to portray Bayan Obo as a national treasure nearly lost. 
The Inner Mongolian Construction Committee (Neimenggu laoqu jianshe cujinhui) under the Communist Party has worked hard to maintain a revised but living memory of local conflicts. Mongolian desires for independence and their collaboration with Japan have been purged from Chinese accounts of the War of Resistance against Japan in this area. In contemporary versions, competing Mongolian, European, and Soviet claims to the region are erased, and the Nationalist leadership is described as seeing the errors of their ways and joining the Communists (Bai 1999). ${ }^{13}$ What is emphasized in the stories, local monuments, and official history around Inner Mongolia-particularly in Hohhot, Baotou, and Bayan Obo-is the unity of the ethnically diverse Chinese nation in the name of revolutionary Communism (Li 2005). As one official in Hohhot wrote: "In Inner Mongolia's glorious revolutionary tradition of opposing imperialism, opposing feudalism and opposing bourgeois capitalism in a revolutionary struggle of over a hundred years, countless Inner Mongolian revolutionaries of Mongolian, Han, and other ethnicities shed their blood and laid down their precious lives" (Chao 2000, 1).

The Mongolian heartland was seen as a frontier to be conquered by Japanese, Soviet, Communist, and Nationalist forces, with various Euro-American interests acting through each of them in different ways. For the first half of the twentieth century, ownership over the region-and therefore the legality of resource extraction-was far from settled. In the Sino-Soviet Treaty of $1945,{ }^{14}$ Stalin agreed that the Soviet Union would enter into the war against Japan on the condition that China recognize the de facto independence of Outer Mongolia (Rupen 1955). ${ }^{15}$ The Nationalist diplomats opposed this, but eventually capitulated when Stalin offered Southern Mongolia to China against the wishes of his Mongolian allies. This is one example in which the frontiers argued over by distant powers are seldom as empty or lawless as imagined in the corridors of power.

This was the first formal division of Mongolia. After Japan's surrender in 1945, Mao Zedong leveraged the rift between the Mongolians and the Nationalists by offering autonomous governance to Southern Mongolia, renamed IMAR, if they joined the Communists in fighting off the Nationalists. After two betrayals of Mongolian hopes for self-rule-once from Japan and again from the KMT-Soviet alliance-and stirred by the hope that Southern Mongolian autonomy might lead to Pan-Mongolian unification, the Inner Mongolian leadership accepted the offer (Liu 2006). These were the conditions under which IMAR was established as an autonomous region in law but as a resource hinterland in practice. An intensive Communist Party education campaign followed, carried out by an ethnic Mongolian cadre elite committed to building a socialist Inner Mongolia ( Wu 1999). Those who continued to fight for true independence or reunification with Mongolia were branded Japanese collaborators or "counterrevolutionaries" and 
later purged (Brown 2007; Bulag 1998). According to some estimates, 10 percent of the region's 1.5 million ethnic Mongolians were executed between 1945 and 1949 (Oyunbilig 1997). Although the establishment of the territory is framed as a glorious sacrifice in the name of Chinese Communism, the establishment of IMAR was necropolitical; that is, built on the politics of death in order to erase competing claims to the region's land and mineral resources.

In two of the primary cases examined in this book, geological prospecting and campaigns of mass death unfolded under the aegis of resource-driven development and nation building on the frontier. ${ }^{16}$ When discussing this history with industry and policy interlocutors across my research sites, I consistently encountered the objection that geology, as an objective science, had nothing to do with political matters such as state-directed campaigns of violence aiming to rid the frontier of those with competing territorial claims. Such sentiments fail to distinguish the collection of facts - which are indeed, in themselves, points of objective data incapable of both help and harm - from the conditions under which such facts were collected and the ends toward which they were deployed. However removed we may perceive ourselves to be from the necropolitical campaigns that cleared the landscape for the benefit of rare earth industries and our easy access to rare earth-enabled technologies, it is absurd to propose that the collection of geological data, their recognition as valid, and their valorization as strategic can be considered in isolation of their social and cultural context. This is especially important in the case of Baotou and Bayan Obo, where violence along ethnic and ideological lines fundamentally shaped the subsequent distribution of benefits and hazards in a manner that continues to inform contemporary policy and politics in the rare earth capital of the world.

The question of who should benefit from exploiting the region's wealth hinged on the question of who conquered this frontier. On the eve of the 1949 revolution, the US Department of State was in negotiations with the KMT to collaborate in the geological "exploration of China for minerals of importance in the atomic energy programs of the two governments" ("Negotiations" 1948, 1018). The Atomic Energy Commission and affiliated private firms sought to secure low-cost monazite sands outside of India, while the Nationalists hoped that guaranteeing high volume sales to the United States would help generate foreign exchange that could then be used to purchase equipment to develop its own nuclear program ("Negotiations" 1948, 748). In exchange, the US Department of State arranged for Chinese scientists to receive scientific training in the United States. This agreement, which was all but approved by late November 1948, never reached fruition as the People's Liberation Army (PLA) defeated the KMT south of Baotou, drove them out of the Mongolian frontier, forced their surrender in the Northeast, and retook Beijing. Shortly thereafter in 1949, the KMT government fled to 
Taiwan with the Sino-American survey documents for Chinese uranium and other minerals, where they would be kept safe from the "unauthorized" hands of Chinese Communists ("Negotiations" 1948, 751). But the geologists, by and large, stayed on the mainland. They maintained that "governments might come and go, but geological knowledge would always benefit the nation, so the development of a geological enterprise was inherently patriotic" (Shen 2014, 186).

The members of China's Geological Society adapted to the prevailing ideology immediately following the founding of the People's Republic of China in 1949. They denounced Nationalist-era practices as "capitalist" and criticized their international collaborators as conducting shallow research to serve narrow business interests and Western imperialism. They characterized US and British activities in the Middle East as capitalist geology, lacking both objectivity and long-term viability. They argued that Socialist geology, by contrast, had a boundless and bright future supporting the development of society and improving the standard of living for all workers (Cheng 1950). To correct the error of their past ways, the Society advised geologists to "learn to grasp the Marxist-Leninist standpoint, perspective, and method" (Shen 2014, 187).

Although much has been made of the setbacks dealt to the development of modern Chinese science by Maoism and the Cultural Revolution, ${ }^{17}$ Oldroyd (1996) observed that the East-West divergence in geological theory during the Cold War was because much geological data was being gathered for military purposes, and was therefore kept secret. In contrast to the early twentieth century, scientists across the globe could not access each other's data. Geopolitical tensions directly hindered the advancement of scientific knowledge. In this case, it was not possible to reach a scientific consensus on the formation of the Earth when scientists in one region could not collaborate with scientists in another. Since China's 1978 reforms and the end of the Cold War, the ideological orientation of China's geological sciences has undergone further revision. Contemporary geologists now criticize the Marxist-Leninist approach as hindering the development of new theories necessary for bringing the discipline closer to the "objective reality of the Earth" (Li 1996).

Nonetheless, geological knowledge continues to be highly politicized and controlled-perhaps because foreign interest in China's mineral wealth persists in living memory. In China, the WTO cases were compared to Soviet, Japanese, and Euro-American imperial interests in the region during the first half of the twentieth century (Wang 2010). As a result, geological practitioners in the government, academies, and state-owned enterprises maintained an air of priesthood: most of the pertinent knowledge one might need was available in writing if the researcher knew precisely where to look, which conferences to attend, and which questions to ask, but there were numerous self-styled gatekeepers who insisted 
that what lies in Bayan Obo was a secret known only to the initiated. The operating theology was nationalism positioned against perceived threats of international resource appropriation.

But the professional pressures to publish in internationally recognized journals means that the debate over the formation of Bayan Obo has migrated from the cloisters of government agencies to international forums. This is somewhat distinct from the question of politics shaping the formation of geological knowledge about the region, but it is important to note that the project of geological knowledge formation about Bayan Obo is not yet complete. Papers continue to be published in Chinese and English on the "Bayan Obo Controversy," which refers exclusively to the geological debate surrounding its origins and formation. Briefly, the controversy concerns how the deposits at Bayan Obo-which are rich not only in rare earth elements, iron, and niobium, but also gold, uranium, and thorium—were formed (Bai et al. 1996; Wu 2007). One camp maintains that they were formed through sedimentary and later low-grade metamorphic processes, citing evidence of the presence of fossils and high amounts of silica, which support theories of an ancient inland sea (Meng 1982). Another argues that, like the general process of formation described in the introduction and chapter 1, they are the result of a carbonatitic intrusion typical of infrequent, low-grade seismic activity (Fan et al. 2006; Le Bas 2006; Le Bas et al. 1992). A third camp has attempted to unify the theories by distinguishing their underlying models and placing them both in a geochronology, concluding that the abundance of minerals suggests that sedimentary, metamorphic, and carbonatitic processes occurred over several heating and cooling periods (Smith, Campbell, and Kynicky 2014, Ling et al. 2013; Ren, Zhan, and Zhang 1994; Wu 2007).

The scientific stakes of the Bayan Obo controversy concern not only the foundational theories of the geological life cycle of Inland East Asia, but also the range of possible conditions under which rare earths are formed. The political stakes concern the validity of the claim that Bayan Obo is in fact an exceptional geological formation endowing China with a unique quantity of rare earth elements (Smith et al. 2014). If Bayan Obo is found to be a truly exceptional formation, then popular fictions concerning China's unique geological endowment gain legitimacy and both sides of the central postcrisis debate gain credence. On the one hand, central government initiatives to slow production, restructure industry, and control the production of geological knowledge about Bayan Obo would then be reasonable measures to preserve an exceptional deposit. International claims that such measures disadvantage the rest of the world, where large rare earth deposits are supposedly lacking, would likewise gain credence. However, if the Bayan Obo deposits were found to be unexceptional, most likely through ongoing comparisons with other rare earth deposits elsewhere, this would validate criticisms that 
both sides engaged in thinly disguised geopolitical exercises with little basis in geological fact, while also underscoring the fact that other countries do have the means to assume greater responsibility for fulfilling their own rare earth needs. This would in turn cast a new light on Deng Xiaoping's often misquoted statement: "The Middle East has oil; China has rare earths." Although provocative, it is too often invoked in Chinese and international discourses to naturalize the dominance of these regions in the production of strategic resources- when in fact the status of the Middle East as an oil exporter is an outcome of historical and political processes rather than geological fact: the top three largest known oil reserves are in the Americas, ${ }^{18}$ and estimates of China's portion of known global rare earth reserves continue to fall.

Deng's comments were made in 1992, decades after oil deposits in the Americas had displaced Middle Eastern sources as the largest known reserves. Viewed in this context, it is hardly a statement of geological determinism. Rather, it is a savvy geopolitical observation on China's position in the global division of toxic labor made at a critical historical moment. The year 1992 marked the conclusion of the first Iraq war and the first year that China's trade and GDP returned to pre1989 levels, driven in no small part by the proliferation of subcontracting networks into China's hinterland as international firms sought to cut production costs by moving the dirtiest and most labor intensive portions of their production chains overseas (Muldavin 1993, 2003). In China's orthodox political discourse of the time, the Persian Gulf War was understood as the enforcement of a resource-based status quo under the banner of capitalist democracy. ${ }^{19}$ In other words, the war was viewed as an exercise to preserve the global division of extractive labor. Deng Xiaoping was commenting not just on the significance of natural resources, but also on the global geography of their production in the first major military exercise following the Cold War. The quote was widely circulated in domestic and international discourse in the years following 2010, as though the crisis represented some intended endpoint of long-term Chinese strategy. Such assertions are ahistorical.

While the production of geological knowledge was central to territorializing Inner Mongolia over the first half of the twentieth century, geological fact has not been the primary driver in contemporary politics surrounding China's rare earth monopoly. Rather, it is the fictions that have driven domestic resource nationalism and revived protectionist tendencies in China, Europe, and the United States. Even as geological fact percolates into popular and official discourse-most commonly with the prim acknowledgement that rare earths are actually not that rare-it has not addressed the often unspoken fears expressed in the logic underlying the Malthusian and Hotelling theories of resource scarcity. Thus, the power of those fictitious logics continues to fuel the fear that the wrong party-whomever that 
may be-will seize control of these strategically vital elements. This is why actual and structural scarcity are so seldom distinguished, and why rare earth elements are classified as critical and spoken of as treasures, despite their relative ubiquity (Associated Press 2013; United States Congress 2011; Wang 2010).

It was these epochal struggles over the Mongolian frontier that provided the motivations and the means to identify, characterize, and produce Bayan Obo's resources as a national treasure. Geology has served as both a practice of territoriality and an exercise of power in multiple contests for the land and resources of Inner Mongolia. Far from being an isolationist measure by a single-minded party state, the process by which Inner Mongolia, Baotou, and Bayan Obo were explored, captured, defended, and rationalized was in fact a transnational military and ideological struggle among powers great and small, all of whom saw in Bayan Obo the raw materials needed to reconfigure a historically contested frontier region into a strategic hinterland from which the enterprises of war and industry might be nourished. Once the sacred mountain was expropriated from Mongolian pastoralists, whether the resources at Bayan Obo should be exploited was never in question. Then as now, the struggles concern the meaning, control, and purpose of mining Bayan Obo.

\section{Death, Life, and Development in the Red Hinterland}

If the material bases of modern statecraft are war and industry, ${ }^{20}$ then the material bases of war and industry are land, labor, and minerals. To transform the minerals within the subsoils of frontier regions into the substance of war and industry, labor must be mobilized on the land to build grand visions into reality. The process through which people reorganize space to sustain themselves and their ambitions is called territorialization. New territorial orders are built with the pieces of the old. In other words, a new order cannot be imposed without expropriating that which came before, yet the imposition of one order does not mean total obliteration of what precedes it (Deleuze and Guattari 1987). What emerges then are "territorial assemblages": spaces characterized by multiple and often antagonistic social orders struggling over the meaning and control of specific landscapes and livelihoods. ${ }^{21}$ When we look at contemporary Bayan Obo as a territorial project, we see the unsettled land use regimes under which contemporary extraction has been carried out as an outcome of historical and ongoing state efforts to consolidate an industrial mining regime-and a particular form of social organization - to suit its evolving purposes. There are many forms this may take in struggles for control over land and resources on the rare earth 
frontier. In China, this has involved violence, military-industrial development, and social engineering campaigns directed at specific ethnic and gender groups.

The remainder of this chapter examines how the state selectively used necroand biopolitics to build a red hinterland. Substituting propaganda for guns as a matter of both compromise and strategy, the state switched from the necropolitics of ethnic and ideological "purges" of the Revolutionary days to the biopolitics of creating desirable frontier subjects in order to achieve developmentalist and geopolitical ends on the IMAR frontier. Necropolitics describes the use of mass death and state-sanctioned killings to achieve political and economic ends (Mbembe and Meintjes 2003). This was one key strategy used to tame the historically autonomous southern Mongolian region. Building up a red hinterland in this space required a different approach. Biopolitics, by contrast, are concerned with managing human life toward political and economic ends (Foucault 2010). In other words, people — with a particular set of cultural values—are essential to developing a robust regional economy. Both necropolitics and biopolitics are manifest in the revolutionary, cultural, and development campaigns that laid the foundation for Baotou and Bayan Obo to emerge as the rare earth capital of the world.

Territorializing IMAR has been a geopolitical project in the conventional and critical senses. Conquering this rare earth frontier was crucial to consolidating national territory, reordering landscapes and lives in profound and irreversible ways. Since 1947, campaigns to transform Baotou and Bayan Obo from Mongolian frontiers into an industrial mining hinterland have proceeded according to raced and gendered social mobilization programs. These campaigns channeled labor and resources to the region while constructing a particular ethnonationalist culture around the mineral resources in Bayan Obo. This involved not only physically relocating people, but also mandating miscegenation, punishing dissenters, and elevating mining-driven industrialization above all else. Mao continued the migration and agrarian resettlement campaign initiated under the Qing dynasty and furthered by the Nationalists. Former nationalist general Fu Zuoyi, who was key in resisting Mongolian-Japanese attempts to conquer Bayan Obo and Baotou, oversaw the project to populate the border region with Han military and civilian personnel (Tighe 2005). The Chinese Communist Party launched a massive "Ethnic Unity" (Minzu Tuanjie) propaganda and education campaign to integrate Mongolians and Han Chinese in the Inner Mongolia Autonomous Region, thereby circumscribing any promised autonomy for southern Mongolians (Various 1948-58). This hinged on an explicitly raced and gendered division of labor orchestrated to advance urban and industrial development on the Inner Mongolian frontier. The objective was to conquer the frontier by building it into the national hinterland through complementary industrial and reproductive measures (Wang 2000). When we examine these campaigns, we are able to 
understand how Bayan Obo in particular emerged as the single greatest source of rare earth elements worldwide. We are also able to better grasp the politics of sacrifice on which China's de facto monopoly is built.

The new Communist leadership was intent on taming the northern frontier and set to work marshaling its people and resources for the project of building "New China." Three core issues defined this agenda. The first were border threats: there remained a restive Mongolian independence movement, while the Soviet Union was determined to incorporate these same regions into its own industrial hinterland (Liu 2006; Nachukdorji 1955; Tighe 2005). The second issue stemmed from the first: the question of urban infrastructure construction and transportation. Third was the convergence of housing, land, and employment crises elsewhere in the country, particularly in postwar Manchuria, in a region where the Soviet Union held investments and privileges on par with those enjoyed by former colonial powers-particularly Britain and Japan. Mao's security strategy relied first and foremost on mobilizing people through migration and social engineering projects meant to Sinicize the frontier ${ }^{22}$ and solve all three problems at once. However unwitting, this strategy laid the industrial, social, and geopolitical foundation for China's de facto global monopoly to later emerge.

Both China and the USSR had territorial ambitions for Baotou that figured into the earliest official relations between the two republics. On December 16, 1949, ten weeks after the founding of the People's Republic of China, the newly established Ministry of Heavy Industry (Zhong Gongye Bu) held its first meeting in Beijing to plan a new steel and metallurgical center in China's interior. That same month, Chairman Mao Zedong left China for the first time on a diplomatic visit to the Soviet Union. Shortly thereafter, in January 1950, Premier Zhou Enlai traveled to Moscow with a group of officials to negotiate a strategic partnership and development assistance portfolio with the Soviet Union (Su 2004). In those cold winter months, both sides hammered out the details of the Sino-Soviet Treaty of Friendship, Alliance, and Mutual Assistance in Moscow, which contained overlapping and conflicting visions for the IMAR frontier. In exchange for development aid and the promise of comprehensive military, industrial, and scientific knowledge-transfer, Mao's delegation granted the Soviet Union special privileges in Xinjiang, Manchuria, and parts of Inner Mongolia.

These territorial privileges represented a continuation of Soviet geostrategic practices since the 1930s, which had been formalized in concessions granted by Chiang Kai-shek in the Sino-Soviet Treaty of 1945 (Kraus 2010). The regionsand their mineral endowments-attributed to the "Soviet sphere of influence" were vast. They included Manchuria, Xinjiang, and what is now eastern and western Inner Mongolia (Li 1998). But it is a mistake to assume continuous rule in practice simply because it was agreed on in Moscow and Beijing. These 
two metropoles were thousands of kilometers away from these immense spaces peopled by nomadic civilizations and divided by mountains and deserts. Although imperial Japan had made efforts at regional integration in Manchuria and parts of Inner Mongolia by constructing roads and railroads, there was very little infrastructure integrating these regions with Beijing, and even less with Moscow. At least twenty-two different ethnic groups inhabited this region from Manchuria to Xinjiang, many of whom maintained strong cultural memory or an ongoing practice of independent self-rule (Liu 2006). ${ }^{23}$ Under the Soviet and the Han Chinese, there were periodic independence movements from East Turkestan, in what is today western Xinjiang, to the eastern reaches of what is today the Inner Mongolia Autonomous Region, a region spanning some four thousand kilometers (Bulag 2004; Rossabi 2004). Across many of these areas, Communist Sino-Soviet rule was little more than a marginal concept with little bearing on everyday life.

State presence had a fluid history in these regions, varying between occasional military occupations, religious fiefdoms, and the periodic rise of city-states and oasis towns (Barfield 1989; Lattimore 1962). Peopled by ethnic others atop immense mineral bounty just beyond the reach of centralized national power, the regions were problematized by Mao and Stalin as lawless and underutilized.

This was precisely Beijing's "frontier problem," as defined in the introduction. The Communist leadership aimed to solve this problem through militarization, industrialization, and resource extraction. One way to make a regime real is to quite literally build it into a concrete, territorial fact. China's formidable contemporary rare earth enterprise emerged from this context of domestic and international efforts to build a diversified industrial base on the Mongolian frontier. However, lacking the necessary infrastructure and technology, Beijing granted resource and military concessions to the Soviet Union to develop oil and other mining interests in Xinjiang and parts of Inner Mongolia. There are two divergent interpretations of this world historical transformation of the Mongolian frontier in both English and Chinese literature. The first is that Stalin forced his Chinese counterparts to accept unfavorable terms in the territorial concessions, in essence creating semicolonies on Chinese territory that Mao later found repugnant (Khrushchev 1971; Zubok 2001). The second view holds that Mao intended to build an industrial corridor to connect the Soviet and Chinese economies and saw sites of ongoing Soviet presence as potential industrial hubs to jumpstart China's economic recovery and stabilization (Kraus 2010, 135; Westad 2003).

Based on the portrayal of these concessions in Chinese newspapers of the time, it appears that central government leadership sought to build Baotou into an industrialized mining hinterland using the means offered by the Soviet Union. In exchange for technology, expertise, and aid, Beijing offered the Soviet Union qualified access to the mineral wealth and territorial privileges in Xinjiang and Inner 
Mongolia's vast spaces (Various 1948-58). Regional state-run newspapers exhorted their readers to strive in every way to deepen the friendship between China and the Soviet Union. The fruits of this relationship were displayed in photographs of military technology, survey reports, and industrial construction featuring Chinese and Soviet personnel ("The People's Construction” 1949; Various 1948-58). Indeed, in assessing "the present character and probable future courses" of Sino-Soviet relations, the US Intelligence Advisory Committee ${ }^{24}$ surmised that China "provides the USSR with a defense in depth, constitutes a valuable potential source of manpower and other resources, and is an important political and psychological asset" (Central Intelligence Agency [CIA] 1952, 4). Although Soviet political and economic influence along China's northern border was extensive, a 1952 CIA report found that "Chinese political and territorial interests have apparently not been sacrificed in the interest of Soviet expansion," and further predicted "an increase in Chinese Communist administrative control" in the region (CIA 1952, 4). However, were the frontier project so firmly and explicitly within Chinese control, it is unlikely that territorial tensions between the two powers would have culminated in the Sino-Soviet split in 1959-60.

The ongoing confusion appears to stem from a tendency to accept orthodox narratives of the founding of the PRC as a stark break with the colonial and feudal past instead of as a dynamic set of historical continuities, where Soviet privilege in Chinese territory was especially salient. Postcolonial China scholarship ${ }^{25}$ has largely accepted the epistemic rupture insisted on in the orthodox founding narrative of the People's Republic of China as historical ontology. This is illustrated by, among other things, the manner in which the Soviet presence in China tends to be treated distinctly from Japanese and European colonialism. As a result, this scholarship has missed the fact that the enduring Soviet presence in northwest China was a direct contradiction to the territorial ideals of new China. The ongoing censorship of archival materials generated by Soviet activities in China from over half a century ago attests to the enduring sensitivity of the territorial narrative.

Yet it is unlikely that the Soviet investment in developing industry, infrastructure, and expertise in Baotou and Bayan Obo would have proceeded without the presumption that these regions would serve as the resource base for a world communist revolution controlled from Moscow-especially given that Mongolia was a Soviet satellite at the time. Provisioning this revolution required transforming the mineral resources in Bayan Obo into the tools of war and industry. This could not be done without a multiscalar effort, from international treaties to enlisting the populace in the cause of building a red hinterland.

Tremendous labor power was required to transform Baotou and Bayan Obo from historically autonomous frontier regions belonging to nomadic polities into 
a red hinterland for Moscow and Beijing. Taming the frontier involved necropolitics, in which some ten percent of the region's ethnic Mongolians were executed, and uncounted others killed in the immediate post-World War II struggles for control over the region. However, it is exceedingly difficult to build an industrial base using mass death. Life and labor were needed. Securing long-term extraction and industrial modernization depended not only on having plentiful labor, but also on establishing a stable, hegemonic claim to the land above these rich geological deposits. Therefore, the state coordinated labor migration in such a way as to encourage permanent settlement and multiethnic integration. For Maoist planners, migration was the solution to the housing, food, and work shortages in eastern China, which would also securitize the frontier by peopling it with Han Chinese. As a result, between 1953 and 1982 the Han population grew by 79.9 percent in Inner Mongolia (Chou 1982 and State Statistical Bureau 1986 quoted in Li 1989, 503-4).

Conditions in war-torn postrevolutionary Baotou and Bayan Obo were hostile compared to those in more established cities (Bi 2007). Winters were bitter, travel was arduous, and the work was dangerous. The first generations that migrated to IMAR via Xikou (Wang 2012) or along the Japanese-built Tianjin-Baotou railroad are regarded as pioneers who toiled hard and "ate bitterness" (chile henduo $k u$ ) in order to build modern China (Chao 2000). State propaganda promoted migration to IMAR as part of national construction and reunification, promising migrants not only the chance to settle down and live the proletarian dream of new China, but also to participate in the glory of restoring millennia-old peaceful and prosperous relations between Han and Mongolian peoples. These campaigns combined a curious mix of socialist modernist sensibilities and sentimental invocations of the second century BCE tradition of sending imperial Han concubines to marry Mongolian tribesmen. ${ }^{26}$

Mao's famous maxim that "women hold up half the sky" was motivated by the need to unleash the labor power of the majority sex in order to realize the herculean task of national construction. The egalitarian recruitment plans were driven by an explicitly reproductivist agenda to territorialize the lands beyond the Great Wall. By exhorting Han women to love "ethnic others," the state intended to quite literally incorporate them into the nation. In addition to these reproductive politics, the PLA enlisted women soldiers to "liberate" the northern frontier regions (Gao 2007). ${ }^{27}$ Others were recruited as teachers, doctors, laborers, and farmers.

Furthermore, there was a common concern that a male-dominated Han population transplanted to the frontier would be unsustainable. As a solution, the PLA recruited Han women from eastern China and sent them to the Northwestern frontier to marry soldiers in couplings arranged by the party: "They were told that the guiding principle was 'the party assigns and the woman agrees'" (Gao 2007, 
198). Women's inclusion in the public sphere was a revolutionary development, but it did not signal liberation from the gendered division of labor: "Although the Communist Party required the employment of more women in government offices and encouraged women to participate in society, the family was the focus of a woman's life, and the ideology of domesticity predominated" on the frontier (Gao 2007, 199).

In Baotou, high-ranking soldiers looked forward to being "rewarded" with a "pretty young woman" from Chengdu or the Northeast ${ }^{28}$ in exchange for their service building and securing the IMAR frontier. ${ }^{29}$ Men came first to build the state-owned Baotou Iron and Steel company (Baogang) and to open the Bayan Obo mine, but "those early leaders knew that having a lot of young men working in the mines and smelting plants would quickly create the conditions for chaos. A lot of men in one place-such a social arrangement is unsustainable. So they recruited women from Sichuan and the Northeast to come live here, and built textile danwei where they could live, work, and start families." 30

Organizing and mobilizing women in Baotou began almost immediately after the founding of the PRC (see figures 8 and 10). The Baotou Municipal Women's

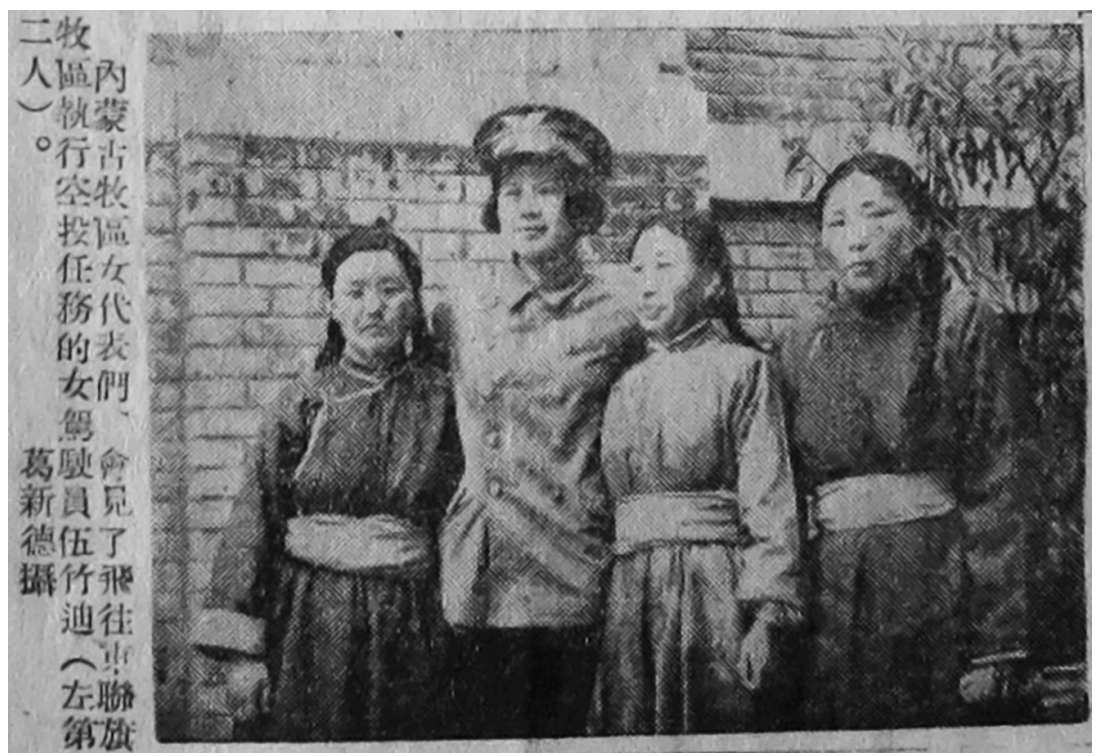

FIGURE 8. Photo from an Inner Mongolia Daily front page article on women's committee progress, June 12, 1952. The photo shows a Han women's committee representative posing with new ethnic Mongolian delegates from a pastoral region. 


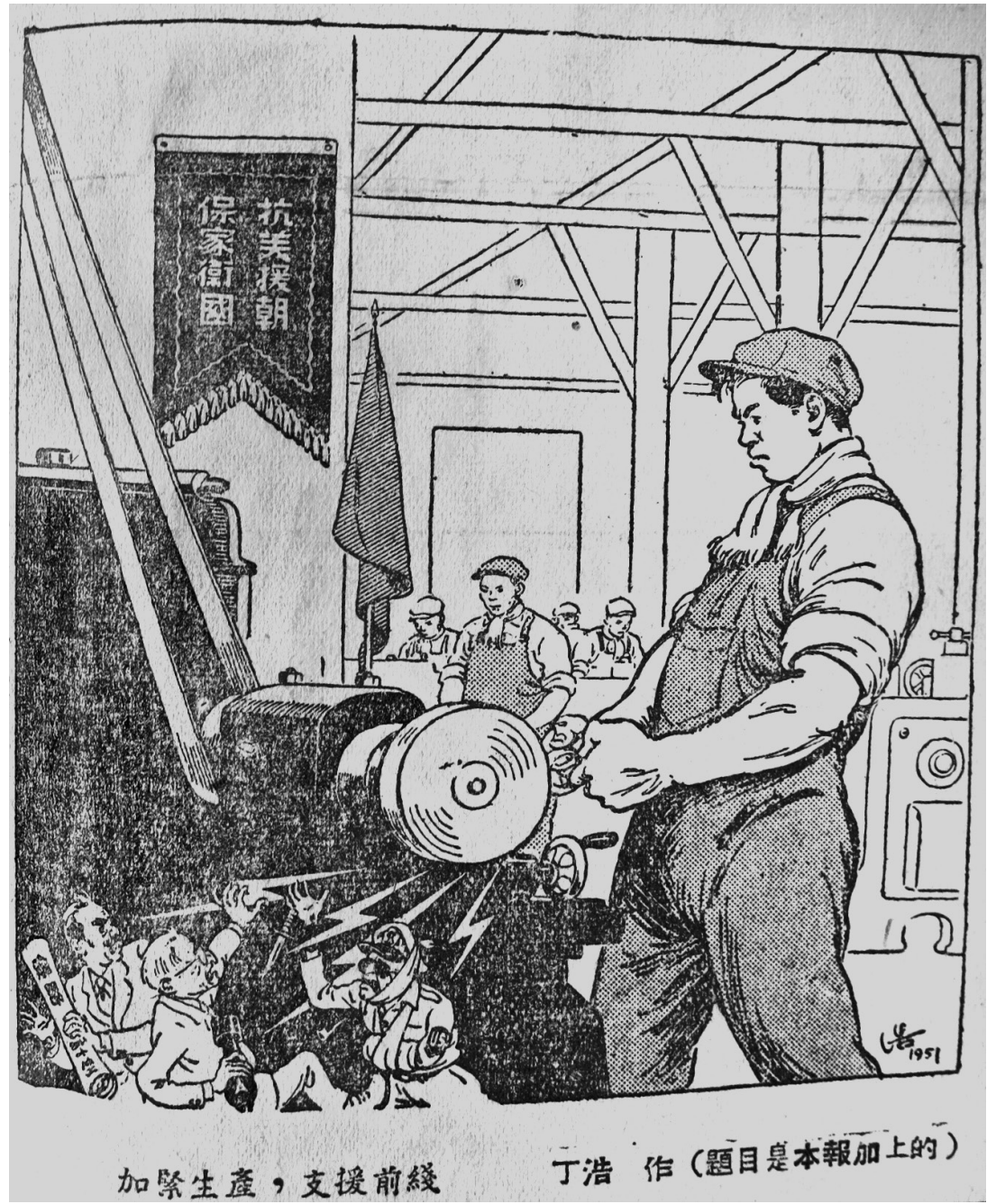

FIGURE 9. An editorial comic on the back page of the Inner Mongolia Daily, March 5, 1952. The comic portrays a male industrial worker thwarting Western imperialists with his machine. The caption reads: "Speed up production, support the frontline."

Source: Inner Mongolian Autonomous Region Archive, Hohhot, Inner Mongolia.

Committee held its inaugural meeting in early December 1949 under the leadership of the Communist Party, less than three months after the liberation of Suiyuan $^{31}$ in September 1949. At this meeting, the women's committee coordinated with the outgoing Nationalist military government planning committee to develop a work plan and organize working groups to build up Baotou. Their pri- 


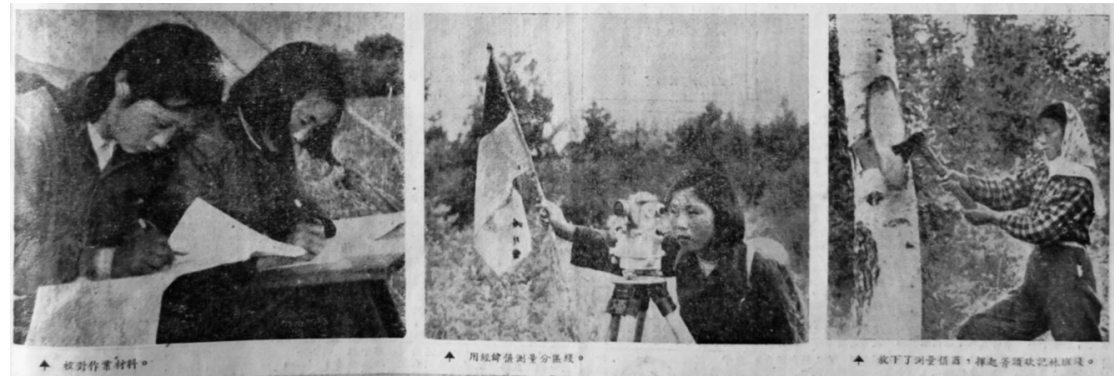

FIGURE 10. A team composed of young Han women shown surveying and cataloging Inner Mongolia's natural resources. Photos from a special to the Inner Mongolia Daily, titled “Young Women Build Socialism!," June 12, 1953.

Source: Inner Mongolian Autonomous Region Archive, Hohhot, Inner Mongolia.

mary tasks were to: "deepen the women's masses at every level, understand their conditions, study thoughts and feelings, propagandize the party's policies [and] build a solid base of mass feeling" (Zuo 2000, 244). This involved visiting every village and town in the municipality and establishing local women's committee offices. The Baotou women's committee focused on integrating women under its jurisdiction into the national military-industrial project. The committee was an important force for integration and subject formation. It identified and celebrated Han and Mongolian peoples' heroines and organized study groups to disseminate examples of virtuous, revolutionary women who helped liberate China, defend Suiyuan, or resist imperialism. Those who opposed the women's movement were branded counterrevolutionaries for failing to follow Mao Zedong's thought and for failing to respect the party's leadership.

In 1957, the Third National Women's Committee Congress resolved to mobilize more women to work in strategic national industries. This was significant for Baotou, where five integrated industries had been established in the preceding five years to build up China's military-industrial complex: Baotou Iron and Steel, which oversaw mining and beneficiation of the Bayan Obo output; Baotou Smelting Plant, which separated metals from the ores; Inner Mongolia First Aviation Factory, which built airplanes for China's nascent air force; Inner Mongolia Northern Heavy Industry Factory, which built tanks and trucks; and China 202 Nuclear Fuels Production Facility, which built critical components for China's atomic and hydrogen bombs. Women's labor and the participation of ethnic Mongolians were essential to building and sustaining these industries.

Mao's comment that women hold up half the sky was meant to liberate them from the "whole feudal-patriarchal system and ideology" (Mao 1967, 44). One conspicuous practice of this former system was the practice of offering high-status Han 
women to outlying princes in order to cement interstate relations and integrate outlying peoples into the Chinese nation through transmission of the Han "kin substance" (Bulag 2002). The practice was vilified even before Mao (Eoyang 1982). But with the intensification of migration it was revived and revised to emphasize revolutionary necessity, and romanticized as an ideal way to integrate IMAR with China.

Women were thus liberated from imperial reproductive servitude, but their reproductive capacity was put into the service of furthering the state's reach into the northern frontier. "Mongolian-Han blood mixing" continues to be fetishized in local and popular discourse. ${ }^{32}$ But this excitement is differentially raced and gendered. Observing the attitudes in one IMAR village, veteran ethnographer D. M. Williams $(2002,97)$ noted that "nobody seems to mind if Mongol men take a Han wife, but residents frown upon 'losing their women' to the Han, even if the couple remains in the village." Conversely, Han male contacts casually expressed the view that a Han man marrying a Mongolian woman was positive because he would get a spirited and healthy wife, while a Han woman marrying a Mongolian was potentially endangered by his wild masculinity. But in most cases, such commentators were quick to point out that a Han woman would have a positive influence on her Mongolian husband, and was thereby serving the nation, just as the ancient imperial brides had.

Such raced and gendered tension cuts across questions of values, territory, and memory, which the state attempts to recast as positive and conciliatory in official publications. One telling example is an attempt to overwrite a particularly painful incident in which PLA soldiers distributed poisoned moon cakes to Mongolian nomads on Mid-Autumn Day during a "Han-Mongolian Social Gathering Festival." One official work published by the Bayan Obo Historical Literature Editing Committee and distributed to all local government offices concedes that "owing to a historical incident," Mid-Autumn Day is "the only unhappy date between the Chinese and Mongolian peoples." However, the "Social Gathering Festival” is still observed because Mongolians reportedly assisted a Central Government geological survey team in Bayan Obo in during the same period in 1950 (Zhao 2010).

The Annals of Bayan Obo extoll the virtues and wisdom of exploiting the local mineral resources. The official narrative praises visionary national investment and party leadership for making mining paramount in Bayan Obo, supposedly bringing international fame, development, prosperity, and happiness to all local peoples. Yet interviews with Mongolians in and around Bayan Obo conveyed the opposite. The name "Bayan Obo" referred to a sacred mountain, which resembled a great stone yurt. ${ }^{33}$ Mining desecrated the sacred peak by literally emptying it out and inverting the mountain into a great hole in the ground: "this is what the Han do to us; they take everything that is ours, even the mountains," said one 
elder Mongolian resident of Bayan Obo. ${ }^{34}$ The feeling of ethnocultural injury was present even among "Sinicized" Mongolians interviewed who were decorated members of the Communist Party. While passing a plaque marking the northernmost point of the Great Wall outside of Bayan Obo, my escort, who was a Communist Party youth volunteer, explained: 'the Han are crazy about marking everything in IMAR. They do that to make the statement: "look everyone, this land is ours. You Mongolians trespassed." 35 Codifying locals as trespassers helps to legitimate the destruction of their lands, whether through mining, urbanization, or other military-industrial campaigns.

The complex historical relations between Han settlers and native Mongolians constitute the cultural landscape on which the military-industrial base in Baotou and Bayan Obo was built, thus informing the distribution of risk and vulnerability to this day. Over several decades, all aspects of life in Baotou, Bayan Obo, and vicinity were reoriented toward building the rare earth-fed military industrial base.

\section{Atomic Aspirations in Cold War Baotou}

These integrated industrial, military, and reproductive projects sustained the atomic aspirations of Cold War Baotou through national and international turmoil. During the Cold War, China's proximity to the "hot" sites of Hiroshima and Nagasaki made revolutionary modernization inseparable from militarization. China's efforts to build the bomb were an anticolonial reaction to both the Japanese imperial occupation of China and the US bombing of Japan. In the shadow of the atomic bombings of those two cities, conquering the frontier to build an integrated military-industrial hinterland took on an urgency that can be difficult for Euro-American observers to appreciate. Building the bomb was a means for the PRC and USSR to build an empire, not just to consolidate power on the Mongolian steppe, but also to project power globally in support of world communist revolution (see figure 9). This fundamentally shaped the industrial geography and cultural landscape of Baotou and Bayan Obo, out of which China's rare earth dominance emerged.

Mining, migration, and transforming the frontier into a red hinterland required extensive cultural and military campaigns, which were organized according to raced and gendered regimes of labor and sacrifice. Fulfilling China's atomic aspirations was no different. In the Museum of Inner Mongolia in Hohhot, the history of ethnic displacement during the development of the nuclear weapons program is memorialized as a patriotic cause that united all ethnicities. Figure 11 shows a life-sized diorama of a Mongolian family leaving their ancestral land on 


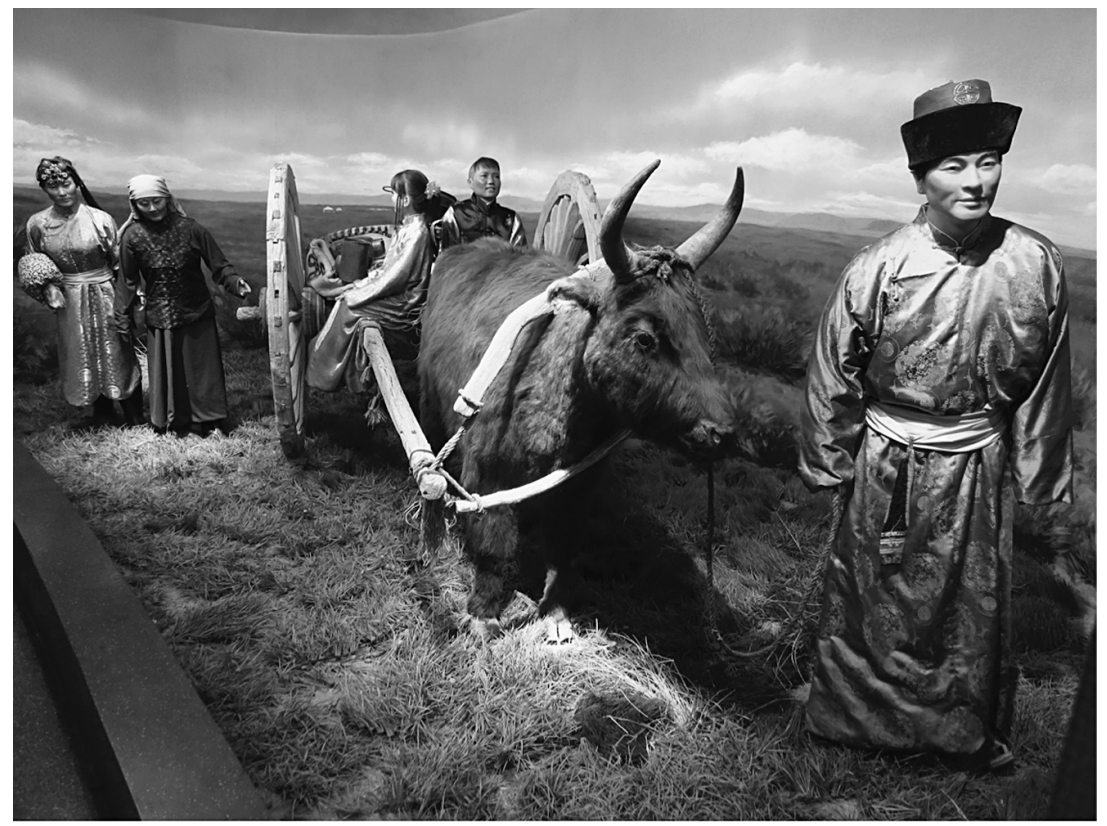

FIGURE 11. A life-size diorama at the Inner Mongolia Autonomous Region Museum in Hohhot, Inner Mongolia, depicting migrating Mongolian families leaving their ancestral lands to support the glorious nuclear achievements of the motherland.

Source: Photo by author, July 2011.

foot to clear the way for the PRC to conduct its nuclear weapons tests. While Mongolian independence activists cite these weapons tests as evidence of Chinese destruction and contamination of Mongolian lands (Oyunbilig 1997), the description at the museum explains that Mongolians made this choice for the glory of the People's Republic of China: “To support the Motherland's national defense and aerospace industry, from April 1958, the Ejina banner let go of tens of thousands of square kilometers of land. The banner government moved to a place 140 kilometers away from the original site... The entire population of the migration covered one third of the population of the banner, more than half of the total livestock, and more than 3,000 mu of arable land" (Klinger 2013a).

On the wall beside the display is a quote from Marshal Nie Rongzhen, architect of China's nuclear strategy and head of the nuclear commission that oversaw the development of the bomb. It reads: "All ethnic peoples made a mighty sacrifice in the service of the national defense of the Motherland. We must work for them in return" (Klinger 2011,4). This mighty sacrifice demanded different things 
from different people. While many Han migrants sacrificed their bodies and their lives in the hard labor of building up a Han-dominated military-industrial complex, many Mongolian natives were forced to resettle. Women of both ethnicities were recruited and coerced into reproductive labor, while men of both ethnicities were compelled to join military and construction campaigns. Resistance was counterrevolutionary and punished by imprisonment, hard labor, and execution.

However, as discussed in the previous section, developing the capacity to mine, process, and produce rare earth-doped goods first required a massive reorganization of society on the order of building entire cities and extensive infrastructure networks. Geological prospecting, the creation of a securitized mining and weapons-manufacturing landscape, and the training of thousands of personnel in the context of the Cold War produced the cultural landscape recognizable in IMAR today and laid the foundation for establishing the "rare earth capital of the world" in China. Much of this history is obscured by the propensity in Anglophone analysis to treat the founding of the PRC in 1949 and Deng Xiaoping's reforms in 1978 as historical breaks beyond which the past could not reach, as though our contemporary rare earth situation arose uniquely from the twentyfirst century. One aspect of this misreading is the tendency in Anglophone literature to characterize the Cold War as "cold." The atomic bomb radically transformed the political calculus of the post-World War II world, but it was difficult for leading analysts in the United States to discern these rationalities in Mao-era governance: "Mao's mind may still envision catastrophe, like victory, as a cumulative effect. He may, therefore, fail to appreciate the dangers of atomic war, the war of massive and instantaneous destruction ... his values are in a different balance from those of the Western world" (Katzenbach and Hanrahan 1955, 338-39).

This is, of course, inaccurate. But it illustrates US establishment thinking about China during the Cold War, wherein those vested with the responsibility to produce knowledge about China did so from afar with few checks in place to correct gross errors in analysis. The correctives that did emerge came from Westerners living and working in China who possessed language competency and ethnographic knowledge, but whose findings tended to be seized or suppressed during the years of the "Red Scare" in the West (Hinton 1966). With a few exceptions, ${ }^{36}$ Anglophone accounts of heavy industry development in mid-twentieth century China tend to emphasize the weaknesses of the communist foe by citing its dependence on the USSR. For example, CIA intelligence report from 1952 found that "except for captured equipment, the Chinese Communist forces are wholly dependent on the USSR for heavy items of military equipment, and the large scale of Soviet logistics support has presumably further increased Moscow's influence with the Chinese military. The Chinese Communist Air Force is largely a Soviet 
creation and is wholly dependent on the USSR for equipment and supply" (CIA 1952, 3).

But there is a parallel story of carefully planned, generously funded, and judiciously managed iron and steel-based industrial production in the Sino-Soviet programs that focused on building an innovation-oriented industrial base in northern China to supply both republics with the hardware of industrial modernity and war. What Anglophone reports missed was that much of Soviet military aid was projected to come from the shared red hinterland of Bayan Obo and Baotou, which would provision the military industrial needs of both countries from a site considered to be remote and secure. The Baotou Project was the most prominent among these joint projects, giving it pride of place as the most successful and comprehensive Sino-Soviet military-industrial project. It was treated as a model for establishing a modern industrial base to produce some of the latest and greatest technology to fuel urbanization, infrastructure, and defense programs.

While detonating atomic bombs on the other side of the world might facilitate the conception of the Cold War as "cold" in the West, it is important to appreciate how differently the US bombing of Hiroshima and Nagasaki were perceived by Japan's neighbors. The Sino-Soviet response was to create a credible deterrent to the threat of a US nuclear attack by building an atomic bomb in China. Set in the Mongolian frontier, the two powers began building up China's nuclear capacity shortly after 1949. China's rare earth and nuclear industry have symbiotic beginnings.

The modernization of war and industry as we have known it in the twentieth and twenty-first centuries was realized to a significant degree through the discovery of new applications of rare earth elements, which, like uranium and thorium, belong to the nonferrous metals family. In the early 1950s, researchers across Eurasia and the Americas were developing rare earth alloys to use in the steel production process, thus transforming the skeletal system of modernity from heavy, rust-prone, and brittle to stronger, lighter, and more durable (Morena 1956, Kent 1953). Rare earths also helped make weapons of war more precise, long-range, and devastating (Bungardt 1959, Hickman 1955). Beginning in 1950 Soviet researchers experimented with nickel-based rare earth super alloys in order to move away from the high-temperature instability of iron-tungsten alloys used during World War II. Rare earths are the key to developing materials that remain stable in temperatures as high as 1,500 degrees Celsius, the sorts of temperatures needed for rockets and airplane engines. Soviet experts shared their discoveries with Chinese researchers in the early 1950s, and by 1956, trial super alloys were being developed in Baotou as a necessary step in China's quest to develop its own aircraft and ballistic missiles (Jiang 2013). In the first and second five-year plans of the 
People's Republic of China, developing these technologies was of utmost importance, not just because they signaled the establishment of a modern industrial society, but also because they were viewed as essential tools for bringing about a world communist revolution.

The first and second five-year plans designated Baotou as a national industrial foundation (gongye jidi) (Geng 2007) and emphasized the importance of rare earth metallurgy in national industrialization:

Industrial development calls for increased production of non-ferrous metals. Since it is still a weak link in our heavy industry, the expansion of non-ferrous metals industry is one of the important tasks of industrial construction under the First Five-Year Plan. ... We must improve and expand experimental and research work to raise the quality of [metallurgical] products to higher standards. We must increase the output of raw materials needed for production of iron and steel, fluxes and refractory metals. (Congress 1955, 58-59)

Exactly when the search for uranium began in China under the PRC is the subject of debate. US intelligence reports from the time estimate that the search for uranium began in 1950, under the auspices of the newly founded Sino-Soviet Non-Ferrous and Rare Metals Corporation joint venture. Following conventional usage, Western observers assumed that "non-ferrous" included uranium and thorium, and so dated the official beginning of prospecting efforts in 1950 (Committee 1960). ${ }^{37}$ However, Lewis and Xue (1988) cite Chinese documents ${ }^{38}$ and interviews with former nuclear program personnel who insist that uranium and thorium were not part of the nonferrous and rare earth prospecting activities in northern China in the early 1950s: "According to one official Chinese account, in 1954 the corporation had put into production the largest oredressing plant for non-ferrous metals (but not uranium) in Northwest China, and thousands of technicians had been trained with young Chinese in charge of most operations.... The Chinese, in working alongside Soviet specialists in the Non-Ferrous and Rare Metals Corporation, undoubtedly did gain experience that was useful to their overall nuclear program" (Lewis and Xue 1988, 76-77)

The official narrative maintains that Chinese geologists had not developed sufficient know-how or technologies to begin uranium prospecting until 1956 (Lewis and Xue 1988). While this is possible, it leaves unanswered the question of what sort of prospecting activities were taking place while Soviet, Polish, and Hungarian experts were training Chinese geologists in the early days of the liberation (Lewis and Xue 1988, 76) or on what basis the United States and Germany were negotiating with the KMT government in the 1930s and 1940s. It is difficult to reconcile the accelerated production of nuclear weapons manufacturing 
facilities - most of which were approved for construction between 1951 and 1956 - with the claim that uranium prospecting did not begin until 1956.

While the authors deserve credit for producing the most authoritative Anglophone account of China's nuclear development to date, I question their conclusion that repeated denial that the Non-Ferrous and Rare Metals Corporation was prospecting for uranium and thorium is sufficient to undermine the findings of other reports published in China and elsewhere. ${ }^{39}$ In my interview experience from 2011 to 2013, it appeared to be standard practice to deny the existence or knowledge of radioactive materials regardless of known facts: only one official working in a public health capacity acknowledged the presence of thorium in the Bayan Obo mine output despite the fact that the rich thorium content of the mine is routinely referenced in scientific and official literature. The operating rationale seemed to be that radioactive materials are a sensitive topic and it was best not to talk about them. Academic specialists, by contrast, exhibited no such compunction.

In sum, the exact year that geological prospecting for uranium began in earnest remains disputed. The stakes of this dispute concern how much credit the USSR, United States, or other European countries should receive for developing China's nuclear weapons program, which later precipitated the development of China's rare earths separations program. If it occurred after 1956, then China had already taken over full control of the nonferrous metals companies as well as other key Sino-Soviet joint ventures. If it occurred before 1956, then it would be necessary to acknowledge that uranium prospecting in China had been led, at least in part, by outside powers (Chi 1990).

Nestled safely between "brotherly states," Baotou was a key site in the production of postliberation China's military-industrial complex. In 1956, the Second Ministry of Machine Building selected Baotou as the location for a large plant to produce uranium tetraflouride, nuclear fuel rods, and materials for hydrogen bombs. With the assistance of Soviet advisors, Plant 202 was built just north of Baotou city and integrated with other industrial facilities built up around the Bayan Obo mine. China's primary producers of tanks and other armored vehicles were also located in Baotou. These facilities were built with the original thinking that Baotou's position between China and the Soviet Union would provide strategic access to the resources at Bayan Obo to provision both powers and be well insulated from potential imperialist aggressors from the West. When China and Russia were on the brink of war in the 1960s, these weapons manufacturing facilities suddenly became very vulnerable. There were periodic shut-downs and evacuation exercises to protect those possessing the nuclear know-how to produce uranium-235 in the event of a Soviet attack on Baotou (Bachman 2007). 
One of the notable things about China's nuclear program is the fact that it developed even in a period of intense turmoil: the Great Leap Forward (1958-61), which precipitated one of the greatest human disasters in history; the Sino-Soviet split (1960-89), which resulted in the abrupt loss of equipment and expertise as Soviet advisors withdrew and cancelled their outstanding equipment deliveries; and the Sino-Soviet border disputes (1961-69), which threatened China's grip on the northern frontier and exposed strategic industries to possible Soviet takeover. Despite this upheaval, nuclear construction - as well as the aforementioned social mobilization campaigns_continued to transform the Mongolian frontier into China's red hinterland.

The Sino-Soviet split and border disputes in the 1960s turned on both powers' tenuous claims to regions peopled by diverse autonomous groups, and highlighted the fact that China's northern border was largely unguarded (Li 1999). In the "Yita" incident of 1962, Soviet agents allegedly urged tens of thousands of local Mongolians and Uighurs in northern Xinjiang to flee to the Soviet Union. Chinese analysts suspected Soviet instigation of numerous other "separatist" incidents along the Mongolia-IMAR border during that time (Fravel 2008). China's response was to depopulate majority-minority regions in border areas deemed "sensitive" and resettle inhabitants in more "interior" regions, effectively emptying the frontier of those who would have competing claims to statehood. Some were conscripted for armed service or manual labor in other northwest development projects (Lewis and Xue 1988). Histories of forced resettlement have been revised to demonstrate a spirit of volunteerism and patriotism on the part of non-Han peoples (see figure 8).

The Sino-Soviet split created a state of emergency as Soviet experts withdrew from Baotou, taking much of their equipment with them. But this state of emergency catalyzed important research and technological developments for China's rare earth and nuclear industries. Innovation in one industry fed innovations in the other. Premier Zhou Enlai prioritized the production of nickel-rare earth alloys, which were essential to make the equipment used to produce uranium tetraflouride at Baotou's 202 Nuclear Fuel Component Plant. As Lewis and Xue (1988, $98)$ note: "To meet the emergency, Premier Zhou Enlai authorized the Baotou Plant to draw 40 tons of these alloys from the central state reserves. The ministry asked a factory, a welding research institute, and an iron and steel academy to cooperate in fabricating the missing apparatus, and the result was the manufacture of China's first heavy equipment made with metal alloys."

This "heavy equipment" was put to work at 202, which produced China's first atomic bomb. After the first nuclear weapon detonation on October 16, 1964, Mao declared that China would not use nuclear weapons in a first strike and would designate them "for defense and for protecting the Chinese people from US threats 
to launch a nuclear war." With China's nuclear weapons manufacturing facilities up and running, senior researchers and technicians branched out to other political and industrial enterprises, such as planning, education, and research.

The nuclear program provided the physical, intellectual, and political infrastructure to further reorganize society in service of military-industrial expansion. Without this, the emergence of Baotou as the rare earth capital of the world would be unimaginable. The symbiotic knowledge economies of the nuclear program planted the seed for China to assume prominence not just with rare earth extraction but, importantly, rare earth separation. Xu Guangxian, considered the father of China's rare earth industry, had attended Washington University in St. Louis, Missouri, to conduct graduate work in chemistry in 1946. He finished his $\mathrm{PhD}$ at Columbia University and returned to China just as the Korean War broke out in 1951; he went to work on China's nuclear program in 1956. There, Xu participated in the race to separate uranium isotopes for China's atomic program. After China's first successful nuclear weapon detonation in 1964, he joined the chemistry faculty at Beijing University where he resumed work on rare earth chemistry. During the Cultural Revolution in 1969, he and his wife's US education implicated them as foreign spies. After being detained in his university dormitory for six months, they were placed in a rehabilitative agricultural labor camp in eastern China until 1971 (Stone 2009).

On his return to Beijing in 1971, Xu was given an urgent military mission to devise a way to separate praseodymium and neodymium (Deng 2009). He applied his previous research in extracting uranium isotopes to rare earth extraction and succeeded after four years (Jia and Di 2009). Separating uranium isotopes is complicated enough, but the proximity in atomic structures and chemical properties among certain rare earth elements posed considerable challenges that had not yet been resolved in any scientific community, anywhere. Recalling the four years of concerted effort required to develop the separation theory and method, he explained in an interview with the Bulletin of the China Academy of Sciences: "In Latin, praseodymium means 'the green twin'; neodymium 'the new twin.' They were the most inseparable twins at that time" (Xu quoted in Xin 2009, 100).

The now elderly scientist relates stories of working long days, following established but time-intensive methods of "shaking funnels"-that is, using centrifuges - and recording extraction data. Then one day he was fed up with established methods. He started to think back on his graduate work in quantum chemistry and the glory days of successful uranium and plutonium extraction in China's nuclear program. He came up with the "cascade theory of countercurrent extraction," ${ }^{40}$ which achieved rare earth oxides of 99.999 percent purity (Xin 2009). In 1974, he traveled to the Number Three Baotou Rare Earth Factory (Baotou Xitu Sanchang) to develop the techniques needed to implement this the- 
ory on an industrial scale. When he announced these findings at the first national rare earths meeting in August 1975, it signaled a fundamental shift in the global division of labor. Until this point, China had exported raw materials and imported separated and refined rare earths from the United States, France, and Japan, who previously controlled rare earth extraction processes (Deng 2009). With this development, it became possible for Western industries to subcontract specific steps in the rare earth refining process to China. The transformation did not happen overnight, but it was the beginning of China's technological superiority in the rare earth sector.

In addition to the political and economic considerations, this theory and method is hailed as a milestone in rare earth separation because it can be applied to ores of different composition on an industrial scale. Much of the research since this discovery has focused on expanding or applying the theory to separating other rare earth elements (Yan et al. 2006). This finding stimulated research throughout China, as reflected in the expansion of the Baotou Research Institute on Rare Earths. Established in 1963 under the former Ministry of Metallurgy Industry (Yang 2013), in its early days the institute was primarily focused on developing alloys for use in regional weapons and heavy industry manufacturing. Xu's innovations stimulated a research and industry renaissance, as government support for identifying new processing methods and technological applications expanded. The center now includes twenty-five research groups totaling approximately seven hundred employees. It also fosters international research collaborations built on the ties established by researchers who completed graduate work overseas, mainly in the United States, France, Germany, and Japan. Collaborative international research and exchange among the world's rare earth scientists has continued, even amid the diplomatic tensions that periodically flare among these states.

\section{Conclusion}

This chapter has shown that that the foundation for China's rare earth monopoly was laid through several distinct yet broadly related processes. Baotou was the site of territorial ambitions for several powers in the first half of the twentieth century. Multiple empires sought to conquer the Mongolian frontier through violence, the production of geological knowledge, and international negotiation.

Contrary to the claims of many Western commentators, China did not possess a grand strategy to use its rare earth monopoly to hold the world hostage. Rather, the development of China's rare earth base emerged from the drive to conquer a frontier, securitize a border and build a red hinterland on the Mongolian steppe between the brotherly states of the PRC and the USSR. At the outset, the aim 
was to provision both republics in their pursuit of world communist revolution. In the aftermath of decades of war and attempts by multiple competing powers to eliminate ethnic Mongolian claims to the region, Mao's government relied on Soviet assistance, domestic migration, and mandated miscegenation to transform the mineral resources in Bayan Obo into the substance of war and industry.

Rare earths were, for much of the time, one part of an immensely ambitious regional development plan. They were strategically valued and therefore became a common link among multiple heavy industries built up around the resources at Bayan Obo. This culminated in a robust, diversified, and in some sectors, a vertically integrated rare earth industry in the red hinterland.

A red hinterland is a comprehensive attempt at regional development, thus conceived in order to sustain a communist society rather than a singularly focused corporate agenda. This historical context is perhaps the least appreciated yet most crucial factor that explains China's rare earth dominance and perceived geopolitical advantage. This is also the most conspicuous difference between the longterm industrial success of Bayan Obo as a site of large-scale industrial rare earth production and the many rare earth mines around the world that have floundered or failed to launch at all. History suggests that the most successful production strategy is one in which rare earth elements are part of a diversified local and regional economy. Laissez-faire political economy has thus far failed to sustain strategic resource production for more than a few years, or in very rare cases, a few decades. But acknowledging this must not be confused with a naïve celebration of Maoist industrialism. How we might take the best lessons from across history to build a more sustainable future is taken up in the conclusion to this book.

The origins of China's rare earth monopoly lie in larger-scale and many seemingly marginally related processes. Reproductivist campaigns directed at different ethnic and gender groups, and the race to build the bomb were two such processes. Atomic aspirations drove the establishment of a military-industrial base on the inland frontier, sustained by an intense cultural commitment even amid national and international turmoil. The nuclear program fit within broader industrial and migration campaigns to stimulate rare earth research and produce today's cultural landscape. These various ideological and geopolitical quests among competing powers laid the foundation for establishing the rare earth capital of the world in China. This came at a tremendous cost, but neither the sacrifices nor the ambitions necessarily offer a replicable model for rare earth dominance, nor are the sacrifices confined to history. 